\title{
SOB O VÉU ISLÂMICO - A DISPERSÃO DE ENUNCIADOS SOBRE A ESCOLHA DO USO DO HIJAB
}

\author{
Under the islamic veil - the dispersion of statements about \\ the choice of wearing hijab
}
Nathalya Karolline Vasconcelos de SOUZA Universidade Federal de Mato Grosso nathalyakarollinevasconcelos6@gmail.com https://orcid.org/0000-0002-1770-5117

\author{
Daniele dos Santos de SOUZA \\ Universidade Federal de Mato Grosso \\ danielesouza@ufmt.br \\ https://orcid.org/0000-0002-7463-7456
}

\begin{abstract}
RESUMO: Neste artigo, analisamos excertos de relatos de duas brasileiras convertidas ao islã optantes do uso do hijab. A partir da noção de discurso e do método arqueológico de Michel Foucault, objetivamos apresentar análises possíveis dos sentidos atribuídos ao uso do véu islâmico como escolha da mulher. Trata-se de uma pesquisa transdisciplinar que se insere no campo da Linguística Aplicada e aborda brevemente as discussões sobre a multiplicidade do islã, o orientalismo na perspectiva saidiana e os sentidos atribuídos ao uso do véu. Concluise que tais relatos colocam em circulação sentidos divergentes dos enunciados dominantes no mundo ocidental que conectam o uso do véu muçulmano à submissão feminina.
\end{abstract}

PALAVRAS-CHAVE: Hijab; Véu Islâmico; Mulheres Muçulmanas.

ABSTRACT: In this article, we analyze excerpts from reports of two Brazilian women converted to Islam who choose to wear the hijab. Based on Michel Foucault's notion of discourse and his archaeological method, we aim to present possible analyses of the meanings attributed to the woman's choice of wearing hijab. It is a transdisciplinary research that is inserted in the field of Applied Linguistics and briefly addresses the discussions on the multiplicity of Islam, Said's perspective on orientalism and the meanings attributed to the use of the veil. It is concluded that such reports put into circulation meanings that distance themselves from dominant statements in the Western world that connect Muslim veiling tradition to female submission.

KEYWORDS: Hijab; Islamic Veil; Muslim Women. 


\section{INTRODUÇÃO}

A figura da mulher muçulmana trajada com as indumentárias islâmicas é comumente percebida no mundo ocidental como a representação de um exotismo inerente ao pouco conhecido mundo árabe. O fetiche causado pelo hijab, o vestuário que oculta partes do corpo feminino, se estende para os demais elementos constituintes do islã. Da combinação entre curiosidade e desconhecimento, concepções surgem no imaginário popular sobre a religião islâmica. É comum notarmos em uma breve conversa que, para muitas pessoas, o uso do véu islâmico é visto como um acessório de uso obrigatório que submete a mulher à regulação de suas vestes pela religião. Para além da padronização sobre o recato das roupas ou o comprimento do cabelo, como ocorre em algumas denominações religiosas cristãs, o uso do véu muçulmano integra uma prática religiosa.Especialmente nas duas últimas décadas, tal prática carrega construções que a associam ao terrorismo, ao radicalismo religioso, à oposição aos valores ocidentais, à subjugação da mulher perante as normas religiosas, entre outros.

Neste artigo, motivadas por reportagens que apresentam olhares diversos sobre o uso do hijab, analisamos os efeitos de sentidos produzidos pelas posições discursivas que confrontam os discursos comumente postos no mundo ocidental sobre o uso do véu islâmico, ou seja, as vozes de mulheres praticantes do islã e que optaram por fazer o uso do hijab. Assim, colocamos em circulação outros possíveis sentidos sobre o uso do véu enquanto uma escolha, de maneira oposta aos contínuos enunciados que conectam tal prática à submissão feminina. Além disso, analisamos também, nos excertos selecionados, as implicações envolvidas nessa escolha, visto que, ainda que se apresentem como optantes livres, tais mulheres não estão imunes aos olhares ainda intrigados daqueles que desconhecem a religião islâmica.

O estudo de discurso proposto se desenvolve a partir das bases teóricas e filosóficas da Análise do Discurso encontradas em Michel Foucault, sendo assim, consideramos como elementos basilares para a análise aqui empreendida as concepções foucaultianas de discurso, formação discursiva e enunciado, bem como seus derivados. Partindo do pressuposto de que as práticas sociais se constituem discursivamente e produzem efeitos de sentido, buscamos a investigação dos sentidos produzidos pelo uso do véu islâmico como escolha por mulheres brasileiras. Para isso, selecionamos excertos de 
dois textos jornalísticos que trazem relatos pessoais de duas praticantes da religião muçulmana. Empreendemos análises de tais excertos não centradas na materialidade linguística, mas sim na verificação dos sentidos construídos em relação ao uso do hijab.

$\mathrm{Na}$ seção intitulada "A arqueologia foucaultiana na Linguística Aplicada", discutimos as principais concepções do método arqueológico foucaultiano e sua conexão com os estudos em Linguística Aplicada que focalizam a linguagem como prática social. Tal abordagem tem o geminado intuito de alicerçar o referencial teórico-filosófico empregado e debater as contribuições de Michel Foucault para a Linguística Aplicada, campo dos estudos linguísticos em que inserimos o presente estudo. Entendemos que os diversos sentidos verificados no ato do uso do véu islâmico não se explicam a partir de um único campo do saber. Desta forma, buscamos na Linguística Aplicada, no método arqueológico foucaultiano e em autores de diferentes áreas das Ciências Humanas e Sociais uma perspectiva múltipla que nos permita investigar a heterogeneidade da referida prática social.

De maneira a apresentarmos a multiplicidade do islã, que se relaciona também com a diversidade de entendimentos sobre a deliberação do uso do hijab por mulheres praticantes da religião, apresentamos um breve contexto sobre o islã. Discorremos a respeito dos aspectos pouco conhecidos sobre a religião muçulmana, tais como as divisões sectárias e as diferentes interpretações do Alcorão. Entendemos que, ao contrário daquilo que é majoritariamente preconizado no Ocidente no tocante ao islã como uma doutrina única, com apenas uma forma padronizada de ser muçulmano, a complexidade deste remonta às origens da religião e perdura nas diferentes práticas de seus seguidores. A visualização de um islã único, não diversificado, radical é, muitas vezes, colocada em oposição à ortodoxia judaico-cristã. Dessa oposição binária, comumente, emanam entendimentos a respeito de outras questões, como a liberdade feminina nas duas entidades. Assim como as religiões cristãs no Ocidente, o islã também não é único e padronizado, visto que se constitui como uma religião de práticas múltiplas entre suas divisões sectárias.

Em seguida, apresentamos a seção de análise em que examinamos excertos de dois textos jornalísticos. O primeiro, intitulado "Tornei-me muçulmana por convicção", foi publicado em 2 de maio de 2018, na seção Eu, leitora da revista Marie Claire. O segundo, 
"A luta de Fátima para usar seu véu islâmico e combater o preconceito", foi publicado na seção Sua vida da Revista Cláudia em $1^{\text {o }}$ de outubro de 2018. Para a seleção dos excertos, coletamos aqueles que abordam a questão do uso do véu sob o viés da mulher muçulmana que o adota por livre consentimento. Buscamos entender como ocorre essa escolha, tendo em vista que a opção pelo uso do véu ainda soa como uma realidade estranha para aqueles desconhecedores das práticas religiosas muçulmanas. Além disso, consideramos também as imagens que acompanham os referidos textos, pois tais figuras não apenas ilustram o texto jornalístico, mas também produzem sentidos sobre a mulher muçulmana.

\section{A ARQUEOLOGIA FOUCAULTIANA NA LINGUÍSTICA APLICADA}

O início do século XXI, ainda em curso, tem se caracterizado como um tempo de expressiva ebulição sócio-cultural-político-histórica, cuja celeridade impacta diretamente no modo de vida e na maneira que pensamos, fazemos e nos colocamos no mundo social (MOITA LOPES, 2006). É neste tempo também em que ganham atenção falas como as de mulheres que se tornaram muçulmanas por convicção e optaram pelo uso do véu no Brasil. Ambos relatos têm se tornado assunto de interesse jornalístico e, conforme se consolida no presente artigo, também são tópicos pertinentes para a pesquisa em Linguística Aplicada, onde a compreensão de questões sociais em que a linguagem exerce papel central tem sido relevante (MOITA LOPES, 2006). Trazer para o campo dos estudos linguísticos as temáticas da agenda contemporânea desafia e impulsiona modos de construção do conhecimento que valorizem o diálogo com os diferentes campos do saber. Se o mundo social contemporâneo é marcado pela heterogeneidade, pela mutabilidade do sujeito social, as ferramentas também precisam acompanhar a fluidez dos tempos atuais. Nas palavras de Moita Lopes (2006, p. 22), “para ver tal mundo, é necessário um novo par de óculos", o qual, ao nosso ver, é preferível que tenha lentes multifocais.

A utilização de lentes multifocais na Linguística Aplicada demanda uma visão crítica capaz de interrogar as práticas de linguagem em cenários plurifacetados, cujas categorias são dinâmicas, e que considere a força produtiva da linguagem na construção do mundo social, na constituição dos sujeitos na e pela linguagem. Tal enfoque representa uma abordagem que advoga a linguagem como prática social e discursiva, que não se 
justifica por si mesma e que é constituída e constituinte do mundo social. Neste aspecto, notamos que essa perspectiva aponta para a demanda de uma Linguística Aplicada que transite, cruze fronteiras e atravesse os campos do saber, que questione, aqui inspirados por Foucault (2008), as condições de existência de determinado enunciado a fim de entendê-lo na singularidade de sua situação. Diante do exposto, com o intuito de compreender as condicionantes sócio-históricas que permitem a circulação e dispersão dos enunciados aqui analisados, bem como as relações que provocam, trazemos à discussão estudos de diferentes áreas das ciências sociais e das humanidades.

A transdisciplinaridade permite que o problema de pesquisa e o modo de investigação sejam explorados por diferentes prismas, motivando uma investigação de modo situado e que considere as relações complexas entre os campos do saber. Pensar um modo de pesquisa e de análise transdisciplinar em estudos de linguagem é compreender que as teias epistemológicas que atravessam as diferentes áreas podem ter mais pontos de contato do que poderíamos imaginar. Há uma possibilidade histórica que perpassa o processo de construção das ideias e conceitos. Apesar da diversidade dos pressupostos teóricos, entendemos ser possível investigar, em uma abordagem transdisciplinar que ultrapasse as fronteiras da disciplina (em seu duplo sentido), as semelhanças, trocas, correlações e regras análogas.

Importante, neste momento, explicitar o convite de Foucault (2008) para o método arqueológico de análise do discurso, para quem o discurso não se trata de um conjunto de signos cuja análise deve desvelar algo, buscar as reais intenções, aquilo que está oculto. $\mathrm{O}$ conjunto de enunciados entrelaçados em uma regularidade, ou o discurso, é entendido como elementos dispersos, não conectados a princípio, sobre o qual a análise observaria tal dispersão e buscaria as regras de formação a que estão submetidos. Foucault (2008) propõe que a análise do campo discursivo compreenda o enunciado em sua singularidade, determine as condições que permitem a existência deste, as regras que o controlam e sua dispersão anônima.

Neste sentido, há uma condição de possibilidade histórica que provoca, na presente década, o advento de uma publicação em mídia de grande circulação sobre o uso do hijab por mulheres ocidentais. Os relatos estão posicionados historicamente em um momento que permite sua existência. O que há de singular nesses relatos para que sejam postos em 
circulação? A que outros discursos remetem, se conectam, se subordinam ou se sobrepõem? Quais sentidos podem produzir? Para além da busca pelos porquês, a compreensão de determinadas práticas sociais, em uma perspectiva foucaultiana, se vincula ao rastreio das condições nas quais o discurso funciona, das circunstâncias que colocam em evidência determinados discursos e não outros, das possibilidades que excluem determinadas formas de enunciação num dado momento, mas permitem a irrupção das mesmas em outras conjunturas.

A compreensão dos excertos selecionados, a nosso ver, roga a percepção das condições que permitem sua existência e circulação. Nessa perspectiva, os textos não são inocentes e refletem um fragmento do mundo social, ou seja, "[...] os textos são políticos porque todas as formações discursivas são políticas. Analisar texto ou discurso significa analisar formações discursivas essencialmente políticas e ideológicas por natureza" (KUMARAVADIVELU, 2006, p. 141). A partir da perspectiva da teoria do discurso de Michel Foucault e de uma Linguística Aplicada transdisciplinar, compartilhamos uma forma de realizar pesquisa que busque traçar os pontos de contato dos enunciados, a fim de investigar os efeitos de sentido produzidos pelos excertos aqui elencados.

Nesse sentido, com o propósito de traçar as conjunturas históricas que permitem a irrupção dos excertos aqui analisados, discutimos, na seção seguinte, a multiplicidade do islã e como isso se relaciona com o uso do hijab pelas mulheres da religião.

\section{A MULTIPLICIDADE DO ISLÃ E O USO DO HIJAB}

O islã é uma religião pouco conhecida pela maior parte da população que vive no mundo ocidental ${ }^{1}$, a qual, majoritariamente, acredita que os devotos daquela se comportam de forma similar ou única. Esta conjuntura advém das questões que envolvem a tradição e as diferentes interpretações do Alcorão,influenciando no pensamento sobre inúmeras questões sociais, políticas e culturais, como o uso do hijab e de vestimentas como a burca.

Em contraposição, conforme aponta Pinto (2010), a religião islâmica é múltipla desde a sua origem, pois, a partir da morte de um dos maiores representantes do islã em

\footnotetext{
${ }^{1}$ A questão da divisão do mundo entre Ocidente e Oriente não se trata de uma segmentação geográfica do globo terrestre, mas de uma oposição binária construída discursivamente e mutuamente de modo a fabricar ambas entidades como opostas (SAID, 2007).
} 
632, o profeta Muhammad, houve a ramificação em duas grandes divisões sectárias: o sunismo e o xiismo. Tal cisão foi motivada pelas rivalidades instauradas acerca da escolha de um novo líder que iria suceder o profeta, já que este não possuía herdeiros do sexo masculino, como era exigido.

Os sunitas defendiam que qualquer devoto fiel ao islã poderia suceder o profeta. Já os xiitas apoiavam Ali, genro e primo de Muhammad, como o próximo sucessor. Porém, os conflitos se tornaram mais evidentes cerca de duas décadas após o ocorrido, dado que pelo terceiro califado consecutivo, um sunita, Othman, havia sido eleito. Portanto, os xiitas decidiram assassinar Othman e, finalmente, cederam a liderança a Ali, que sofreu com oposições e foi assassinado. Com a persistência xiita, Hussein - neto do profeta reivindicava o trono no Iraque, no entanto, foi assassinado pela oposição sunita, que almejava permanecer com o poder centralizado (PINTO, 2010).

Baseando-se nos conflitos supracitados, iniciados no ano de 632, é importante enfatizar que as desavenças entre as tradições sectárias sunita e xiita ocorreram processualmente e se perpetuam ainda atualmente. Esses grupos de oposição se consolidaram de formas distintas quanto às suas doutrinas, seus rituais, suas instituições, entre outros (PINTO, 2010). Além dos sunitas e xiitas, há também outros grupos que compõem divisões sectárias menos expressivas em relação ao número de seguidores, como os sufistas $^{2}$ e os kharijitas ${ }^{3}$. Por conta disso, seguindo a concepção exposta de pluralidade da religião dos muçulmanos, não é concernente retratar o islã como uma religião com doutrina única que é seguida irrefletidamente.

Dada a elucidação de um breve histórico do islã e sua multiplicidade, sugerimos considerar que a fé se reflete também nos costumes destes povos (assim como em outras religiões), como a questão do uso do véu islâmico pelas mulheres, que é percebido como imprescindível para determinados muçulmanos, mas dispensável para outros. Acrescido aos diferentes modos da prática religiosa islâmica, os enunciados que advogam pelo uso ou não do véu se conectam a grupos de formação diversos, inclusive aqueles motivados por razões exteriores à prática religiosa. A "mulher com o véu” é elemento que perpassa

\footnotetext{
${ }^{2}$ Advindos do sufismo, vertente mística do islã.

${ }^{3}$ Grupo voltado à valorização das leis do Alcorão, independentemente do líder, ou seja, não defendem, mas também não se opõem, que a maior representatividade esteja centrada em um sucessor da família de Muhammad, priorizando somente aquele que melhor gerenciará a sua fé.
} 
formações discursivas distintas e, muitas vezes, contrárias entre si. A esse respeito, por exemplo, temos as diferentes visões das vertentes islâmicas (PINTO, 2010; GROSFOGUEL, 2016), o discurso colonial ocidental, para o qual tais mulheres devem ser salvas da opressão, projetos governamentais de secularização, como aquele ocorrido no Iran na década de 30, ou ainda a proposta de feministas islâmicas contemporâneas, para quem “[...] esto es um asunto que cada mujer musulmana debe decidir y no que los hombres deban decidir por ellas"4 (GROSFOGUEL, 2016, p. 28).

Dessa forma, podemos inferir que o uso do hijab pelas mulheres muçulmanas não é uma lei geral obrigatória, já que depende da vertente religiosa a qual cada uma é vinculada e das motivações do grupo a que pertencem. Ademais, em sua origem, o véu era utilizado com outros intuitos:

[...] historicamente, a função do véu era proteger as mulheres da areia trazida pelo vento, lembremo-nos de que o islã foi revelado na desértica Arábia. Economicamente, era um símbolo de status: a mulher que ao mesmo tempo merecesse o cuidado e tivesse os recursos para providenciá-lo podia ser humilíssima - mas nunca uma escrava, a quem a peça, aliás, era vetada. Socialmente, desestimulava as investidas masculinas, ao deixar todas as mulheres indistintas pela uniformidade visual [...] O status, originalmente financeiro, se tornou religioso: cobrir a cabeça diferenciava as crentes das infiéis (LIMA, 2016, p. 80-81).

O uso do véu é marcado pelas condições históricas, geográficas e culturais, não sendo possível, portanto, demarcar uma verdade única dentre as conflitantes concepções sobre ele. Proteção contra a areia do deserto, símbolo de status socioeconômico, vestimenta de recato, paramento religioso, entre outras, são representações governadas e construídas pela/na linguagem. A esse respeito, ressaltamos que a "verdade" sobre o uso do véu não se trata das dicotomias entre o certo e o errado, ou o verídico e o falso, visto que "a verdade está circularmente ligada a sistemas de poder, que a produzem e apoiam, e a efeitos de poder que ela induz e que a reproduzem." (FOUCAULT; MACHADO, 2012, p. 54).

Apesar de o hijab ser comumente visto de forma negativa e retrógrada no mundo ocidental, o olhar de muitas mulheres muçulmanas acerca dessa questão pode não ser

\footnotetext{
4 "[...] isto é um assunto que cada mulher muçulmana deve decidir e não que os homens devam decidir por elas" (tradução nossa).
} 
hostil, já que sua utilização pode simbolizar a fé e o orgulho de fazer parte da religião (LAMRABET, 2016; ZOLIN VESZ; FELTRIN; SOUZA, 2019). A jornalista libanesa Samira Zenni, que vive no Brasil, entrevistada por Lima (2016), justifica a não utilização do hijab como forma de expressão de sua religiosidade.Apesar de contrária ao pensamento de alguns xeiques, que a criticam, Zenni considera que, se utilizasse o aparato religioso em seu ambiente de trabalho, acabaria chamando mais atenção por se destacar em meio a outros colegas de trabalho, que utilizam as roupas mais convencionais nessa profissão, roupas sociais em geral.

Além da estigmatização do uso do véu no Ocidente funcionando como elemento materializado da opressão das mulheres muçulmanas, Lima (2016) aponta também outras situações ocorridas em seu experimento de utilizar o hijab durante nove dias na capital do Estado de São Paulo. A jornalista se ateve a frequentar os mesmos lugares que costumava ir. Durante a sua pesquisa, constatou a postura tomada pela maioria das pessoas ao seu redor, alterando seu semblante diante dela, com olhar piedoso, vindo a ser mais gentis (também advindo da pena de lidar com uma mulher que carrega o estigma de submissa e oprimida). A autora relata ainda o embaraço quanto à sua mãe, que não legitimava seu trabalho (LIMA, 2016).

As disparidades encontradas nas imposições ou não da utilização obrigatória do véu pelas mulheres muçulmanas têm em vista perspectivas diferentes tanto de pessoas não praticantes quanto dos adeptos da religião islâmica, pois a questão do véu não é consensual mesmo para os membros do islã. Por outro lado, conforme apontado por Lamrabet (2016), o texto corânico traça orientações e diretrizes a homens e mulheres sobre uma ética global de decência, respeito e moderação em relação ao corpo, sem especificar uma maneira específica de se vestir. Ao abordar os diferentes discursos islâmicos contemporâneos sobre o hijab, a autora apresenta as visões contraditórias que partem da interpretação do texto corânico e da jurisprudência islâmica: o véu como "proteção" (posicionamento defendido pela maioria dos ulemás xiitas e sunitas); o véu como resistência política e emblema identitário (defendido por militantes do islã político e intelectuais); ou ainda o uso do véu como recomendação e não obrigação (posicionamento de xiitas e sunitas reformistas) e, por fim, a noção de recomendação-eleição (posicionamento que deixa às mulheres a autorregulação de seus corpos). A diversidade de 
proposições, advindas de diferentes condicionantes, demonstram o embate constante dos múltiplos enunciados na arena discursiva.

Dado o exposto, indicamos brevemente a complexidade, a diversidade e a heterogeneidade existente dentro da religião islâmica, variando de acordo com o país de origem e ao grupo ao qual o sujeito pertence. Por conta disso, não se deve considerar esta religião como única, pois é praticada em diversos países e regiões do mundo, podendo, ainda, variar de acordo com a cultura e história daquele local e, com isso, a multiplicidade do islã se revela.

A pluralidade percebida no islã, em suas práticas e na obrigatoriedade ou não do uso do véu, exprime a dispersão de enunciados que se pretendem mais verdadeiros do que outros e cuja existência está imbricada em condições de possibilidade histórica. Para Grosfoguel (2016), a melhor resposta para a obrigatoriedade ou não do uso do hijab foi proferida pela iraniana, Prêmio Nobel da Paz, Shirin Ebadi, ao ser questionada se apoiaria a França na promulgação da lei contra o uso do véu nos espaços públicos. Para Shirin Ebadi, a mulher desafia o poder no Irã ao remover o véu, mas, na França, o poder é desafiado quando ela coloca o véu, já que nenhum Estado deveria decretar como uma mulher deve se vestir. Notamos que o uso do véu islâmico mobiliza pontos de vista díspares, que, na análise do campo discursivo, nos fazem entender as condições que possibilitaram o funcionamento dos enunciados selecionados que analisamos na seção seguinte.

\section{SEÇÃO DE ANÁLISE: TECENDO AS TRAMAS DO HIJAB}

Nesta seção, analisamos dois excertos de reportagens de mulheres que optaram pelo uso do hijab, inicialmente enfatizando as imagens vinculadas aos textos e, posteriormente, alguns trechos de ambas reportagens. O primeiro, intitulado "Tornei-me muçulmana por convicção", pode ser encontrado na seção Eu, leitora da revista Marie Claire e foi publicado no dia 2 de maio de 2018 e, em constante, "A luta de Fátima para usar seu véu islâmico e combater o preconceito", encontrado na seção Sua vida da revista Cláudia e publicado em $1^{\circ}$ de outubro de 2018. Ambas as seções podem ser localizadas por meio de endereço eletrônico e possuem o intuito de abrir espaço para que as leitoras possam narrar elementos da própria vida. 
Essas seções se enquadram em partes específicas das revistas, nas quais notamos a presença de variados relatos excepcionais. Exemplificando, na seção Eu, leitora, da revista Marie Claire, podemos verificar uma reportagem intitulada "Durante seis meses, namorei o cara que me assaltou"; e na revista Cláudia, na seção Sua vida, há um relato denominado "Casal abandona filha adotiva e a acusam de tentar matá-los". Esta analogia tem o intuito de explanar que relatos tão excepcionais como um assalto ou uma queixa de tentativa de homicídio compartilhem das mesmas seções, nas respectivas revistas, em que se encontram os relatos de mulheres convertidas ao islã e que decidem optar pelo uso do hijab de maneira espontânea.

A partir do entendimento de que os elementos visuais recebem grande destaque nas reportagens, analisamos preliminarmente os conteúdos das imagens. Entendemos que as imagens apresentam um importante papel no convite ao leitor para entender mais sobre a realidade daquilo que a fotografia representa, estampando (ou não) o retrato de um(a) verdadeiro(a) leitor(a) de história atrativa, porém igualando-se ao leitor na condição de também o ser. Posteriormente, trataremos dos títulos, juntamente com os excertos de ambos os textos selecionados.

\section{Análise das imagens - quais as cores do tecido?}

A compreensão da linguagem como prática discursiva, norteadora desta pesquisa, nos permite investigar o conjunto de enunciados coletados a partir de uma perspectiva de análise do discurso que busque a potencialidade discursiva não só dos excertos verbais, como também das imagens que compõem os textos jornalísticos. Assim como não nos contemos à análise estrita da materialidade linguística, do mesmo modo não limitamos a análise das imagens a seus signos semióticos, sua composição, cor, iluminação. Considerando tais fotografias como componentes de uma rede de enunciados que provoca sentidos no mundo social, as analisamos em seu funcionamento discursivo, investigamos a que remetem e a que formações discursivas se entrelaçam.

As imagens selecionadas se encontram em destaque nos relatos das leitoras e compõem o texto jornalístico. A figura 1 se refere à reportagem de título "Tornei-me muçulmana por convicção", da revista Marie Claire, e a figura 2 pode ser encontrada na revista Cláudia sob título "A luta de Fátima para usar o véu islâmico e combater o 
preconceito". Entendemos que o contraste percebido em ambas figuras acentua a diversidade de percepções sobre a mulher que traja o véu.

Figura 1: Representação de Doha

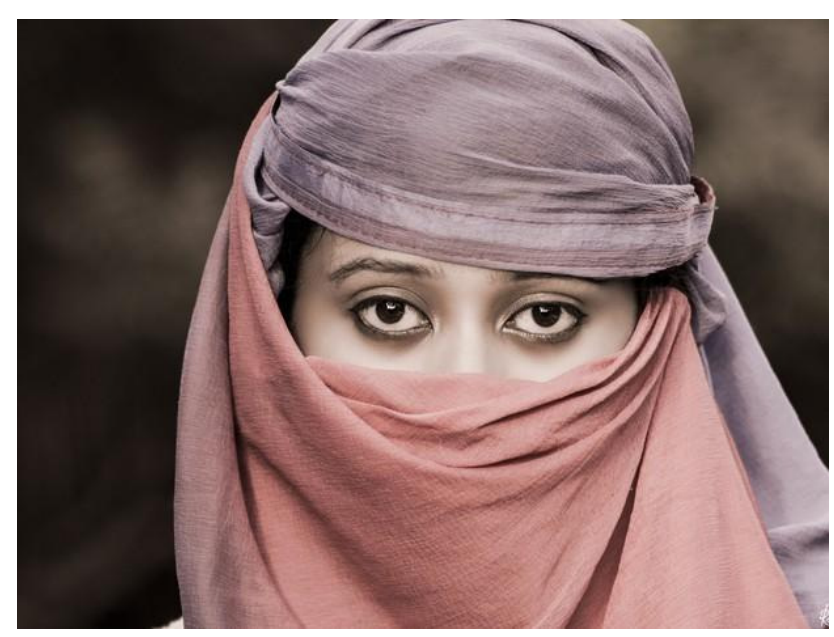

FONTE: Revista Marie Claire.

A figura 1 foi selecionada para representar "Doha", sendo importante evidenciar que o referido nome é fictício, assim como a imagem utilizada e demais nomes das personagens do relato. Tal sigilo adveio do desejo da relatora, conforme informado na reportagem. A imagem apresenta uma mulher com um véu que cobre os cabelos e revela somente os olhos. Não há na fotografia indícios do cenário em que ela está, sendo a figura feminina trajando o véu, em tecido rústico e de cores discretas, o principal elemento do retrato. A posição do olhar da mulher retratada não é altivo ou centralizado, o que coopera para a visualização de uma mulher que olha de baixo para cima. A escolha da fotografia de uma mulher com véu semelhante ao niqab (véu que revela apenas os olhos) pode provocar o interesse e curiosidade do leitor, além de, por outro lado, reforçar a visão de que as mulheres muçulmanas estão escondidas, encobertas, são desconhecidas tal qual o Oriente. Embora o relato traga a informação de que Doha utilizasse o hijab (véu que cobre o cabelo e o colo, mas não esconde o rosto), a reprodução da figura da mulher utilizando o niqab ou a burca é bastante recorrente no imaginário popular. Neste caso, percebemos que tal estratégia é reforçada pela possível intencionalidade de instigar a atenção dos leitores da revista com o uso de uma fotografia que atenda ao estereótipo orientalista de mulher muçulmana. 
Apesar de a entrevistada ser brasileira, o nome fictício é de origem árabe e denomina a capital do Emirado do Catar, país de maioria sunita. A denominação da brasileira com um nome árabe é mais um dos nós que entrelaçam o islã a concepções orientalistas, que retomam os diversos sentidos construídos ao longo do tempo sobre o mundo árabe e a religião islâmica. Em uma construção marcada por relações de poder, a representação da mulher muçulmana que se esconde sob o véu é comumente percebida no Ocidente através dos filtros do orientalismo ${ }^{5}$, ou seja, a temática retoma as oposições modernidade versus tradição, liberdade versus opressão, que constroem Oriente e Ocidente como entidades opostas (SAID, 2007; BASTOS, 2016).

Figura 2: Luta para usar o véu

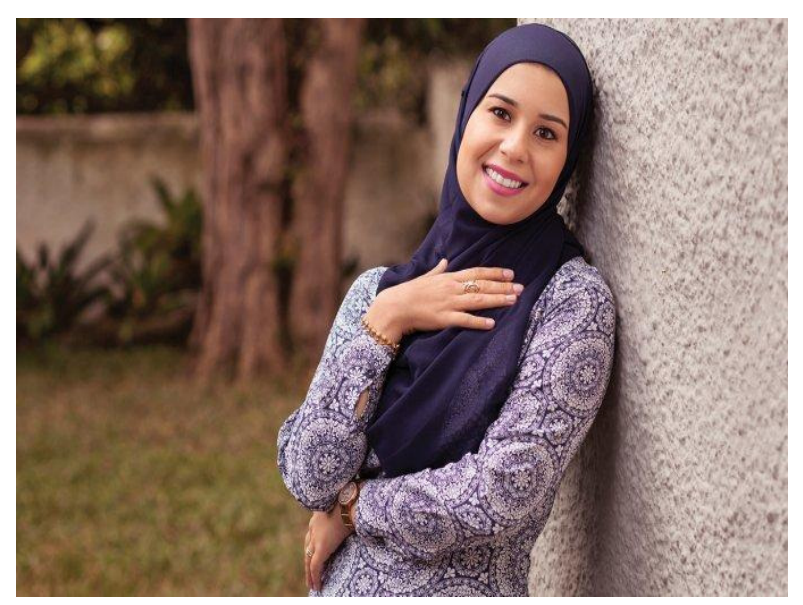

FONTE: Revista Cláudia.

De modo oposto, a figura 2 é uma fotografia da entrevistada, Fátima, que traja um hijab, mostra o rosto e estampa um sorriso, o que permite uma leitura de seu contentamento consigo mesma e, provavelmente, da felicidade em poder compartilhar a sua história de vida com outros leitores. Ao contrário da imagem anterior, o retrato de Fátima é mais revelador sobre a entrevistada: sua roupa é estampada, ela utiliza anéis, pulseira e relógio, há batom em seus lábios, seu olhar encara o leitor e ela estampa um sorriso amigável. Além disso, o cenário ao ar livre transmite certa sensação de liberdade,

\footnotetext{
${ }^{5}$ O orientalismo é conceituado por Said (2016, p. 29) como "um estilo de pensamento baseado numa distinção ontológica e epistemológica feita entre o Oriente e (na maior parte do tempo) o Ocidente". Para o autor, o Oriente foi produzido discursivamente de modo a contrastá-lo ao Ocidente. De acordo com a tese saidiana, ao se construir um Oriente primitivo, belicoso e bárbaro, o Ocidente é produzido, em contraste, como moderno, pacífico e civilizado.
} 
além de leveza na expressão corporal. A leveza também se exprime no véu transparente de Fátima, que, apesar de preto, se assemelha à seda, diferentemente do tecido rústico da imagem anterior. Tal funcionamento discursivo se conecta e reforça o título da reportagem, pois, a princípio, espera-se daquele que luta e combate algo certa emancipação. É importante para a construção dos sentidos do relato de Fátima que não seja associado a seu relato a imagem da mulher oprimida e coagida a usar o véu.

As figuras 1 e 2 podem ser consideradas antagônicas em alguns aspectos, como a diferença entre os véus, pois a primeira está vestida em um niqab, que esconde grande parte do rosto, revelando apenas a região dos olhos e uma pequena parte do rosto. Diferentemente, a segunda utiliza um hijab, que deixa todo o rosto à mostra, conferindo certo grau de leveza e amenizando a ideia de opressão. Na figura 1, apresenta-se uma mulher de olhar que, aparentemente, carrega tristeza e apatia, além de estar com seus olhos fixos (em um direcionamento de baixo para cima) no primeiro contato com o leitor da revista, de forma a produzir sentidos que possam se coadunar com os demais enunciados e mobilizar no imaginário do leitor a durável e fixa ilustração da mulher sob o véu islâmico que precisa ser salva.

Por conta do uso de uma fotografia que não ilustra realmente a protagonista da história, as imagens dos relatos encontrados nas revistas Marie Claire e Cláudia parecem ser tão díspares, quando na verdade se distanciam essencialmente na apresentação do elemento visual ao leitor por uma questão editorial, não correspondente necessariamente ao contexto em que as histórias de vida foram contadas. Assim como a figura de Fátima colabora para a construção da imagem da mulher moderna e ocidental que tem a escolha como um direito, a figura que ilustra o relato de Doha também funciona como ferramenta de produção discursiva. A dificuldade de conciliação entre a liberdade dessa mesma mulher ocidental com o estereótipo da mulher muçulmana submissa é enfatizada na apresentação de uma mulher anônima trajando o niqab. Dessa forma, as figuras 1 e 2, em nosso ponto de vista, são contrastantes, embora se assemelhem na ideia geral: mulheres que utilizam o véu islâmico.

\section{Análise dos excertos - entrelaçando os fios}

Nesta subseção, analisamos excertos retirados de ambas as reportagens analisadas, 
tendo como início aqueles que se encontram em destaque, logo abaixo do título e, em seguida, os demais excertos que consideramos relevantes para esta análise. De modo a entrelaçar ambos os textos, por entendermos que se conectam discursivamente, intercalamos os excertos em alusão aos atos da confecção de uma veste - seja da agulha que vai e volta na costura ligando dois pedaços de pano, seja dos fios que se entrecruzam na produção de um único tecido. Entendemos que não só de seda, chiffon ou algodão se fazem os véus islâmicos, mas também de relações de poder que produzem e apoiam verdades sobre o mesmo, que permitem a durabilidade de concepções acerca do uso do hijab.

\section{Excerto 1 - Tornei-me muçulmana por convicção}

A paulistana Doha, 25 anos, sempre quis ser independente. Fez faculdade de administração, trabalha com sustentabilidade e comprou o próprio apartamento. Ao se converter ao islamismo, não mudou seus valores. Ela conta como concilia a vida de ocidental com a nova fé.

O excerto 1 evidencia o recorte do texto intitulado "Tornei-me muçulmana por convicção", constante na seção Eu, leitora da Revista Marie Claire. Importante destacar que tal seção é composta por histórias relatadas e enviadas pelos leitores através de formulário disponível no site da revista eletrônica ou coletadas por depoimentos a jornalistas do canal. Com histórias em tom confessional, é possível notar que a seção traz histórias de vida que, de alguma maneira, se sobressaem ao senso comum, o que é verificável nos títulos dos referidos relatos. O depoimento de Doha, coletado por uma das jornalistas da revista, foi publicado em dois momentos distintos, inicialmente em 31 de outubro de 2011 e novamente em 2 de maio de 2018. Ambos os momentos parecem se relacionar a períodos em que a temática muçulmana estava em maior evidência: em 2011, em decorrência dos 10 anos do ataque às Torres Gêmeas, e em maio de 2018, provavelmente relacionado ao período do Ramadã (16 de maio a 14 de junho de 2018).

O destaque da fala da leitora Doha aponta a um só tempo o tom confessional da referida seção, escrita em primeira pessoa do singular, bem como evidencia a escolha consciente de uma mulher que goza da liberdade ocidental, visto que, aos 25 anos, ela já é independente financeiramente, faz faculdade, trabalha e comprou o próprio imóvel. Ao apresentar brevemente quem é a brasileira que se tornou muçulmana, acompanhado de que sua conversão "não mudou seus valores" e que ela "concilia a vida de ocidental com a 
nova fé", é possível notar a dicotomia entre dois modos diferentes de vida. Tal qual preconiza Said (2007), o modo de vida ocidental e oriental são construídos discursivamente como antagônicos, sendo assim, ao ressaltar a independência da leitora e seu estilo de vida, que retoma a liberdade feminina ocidental, o texto parece colocar em evidência dois pontos principais: a conversão ao islã pode ser uma escolha livre e consentida; há conciliação (embora esta precise ser contada, já que é desconhecida pelo senso comum e infere estranheza) entre a vida ocidental e a fé islâmica. A imagem da mulher ocidental livre, independente, que opta por uma fé cujas práticas são construídas como antagônicas àquilo que a entidade Ocidente representa, faz oscilar as verdades colocadas em circulação a respeito da mulher muçulmana, suas vestes, submissão e, como nos apresenta Abu-Lughod (2012), sua necessidade de ser salva pelo Ocidente.

Ademais, "tornei-me", no título da reportagem, indica a decisão da mulher, construída discursivamente como livre e ocidental, de tornar-se muçulmana. Ela não foi transformada, mas tornou-se sem que lhe impusessem tal conversão. $\mathrm{O}$ que se consolida com "por convicção", que reforça a ideia de uma ação por escolha própria, reiterando o seu papel de uma mulher que enfrenta os desafios sociais, por mais surpreendente que seja tornar-se uma muçulmana, sugerindo, assim, um comportamento inusitado. Dessa forma, infere-se que as mulheres ocidentais são, indubitavelmente, livres. A incompatibilidade entre a liberdade ocidental e a fé islâmica é reforçada pelo subtítulo "Ela conta como concilia a vida de ocidental com a nova fé", o qual transmite a ideia - ao comparar - de que a mulher do Oriente seja, em todo (ou quase todo) caso, oprimida, além de contrastar mulheres a partir da ótica orientalista que opõe as entidades oriental e ocidental. O verbo "conciliar" funciona como um elemento que também ressalta tal entendimento, pois só é necessário conciliar partes em desarmonia. Em outras palavras, a "nova fé" de Fátima é percebida como um componente em discrepância com a vida ocidental.

\section{Excerto 2 - A luta de Fátima para usar seu véu islâmico e combater o preconceito \\ "Sempre quis usar o véu, mas sentia medo por estar no Brasil. Se morasse no Líbano, teria colocado antes, porque lá é normal".}

O excerto 2 refere-se ao texto intitulado "A luta de Fátima para usar seu véu islâmico e combater o preconceito", encontrado na seção Sua vida da Revista Cláudia. 
Vale ressaltar que a referida seção trata de assuntos variados e, entre esses, temas inusitados que visam manter o interesse de seus leitores nas edições da revista. Sendo assim, depreende-se que uma reportagem de temática que aborda a vida de uma mulher muçulmana é, no mínimo, incomum. Similarmente à narrativa de Doha, a história de Fátima se trata de um relato excepcional, surpreendendo os leitores da revista, já que relata a história de vida de uma mulher anteriormente livre, que se propôs a lutar pelo uso do véu islâmico, aquele que se pressupõe como sendo um símbolo marcante da opressão vivida pelas mulheres muçulmanas. Outra semelhança se relaciona à escolha espontânea da protagonista do relato, que toma a decisão de utilizar o hijab, se opondo à ideia implícita de imposição.

O título é composto por elementos que reforçam a decisão de Fátima como uma escolha, além de demonstrarem que tal escolha se constituiu como um ato de embate. $\mathrm{O}$ substantivo "luta" e o verbo "combater", encontrados no título do texto, demonstram o demasiado esforço de Fátima ao decidir, finalmente, usar o véu do islã, superando o seu medo de usá-lo no Brasil e tentando combater o preconceito que se tem sobre as mulheres que o utilizam. A sua escolha, portanto, é construída como advinda de sua própria decisão e não da imposição por outrem ou por entidade religiosa ou cultural, muito embora, em trecho da reportagem, o jornalista apresente a noção de que o véu é uma prática requisitada pela religião islâmica.

O sentido produzido por "luta" e "combater" retomam uma formação discursiva que constrói o islã como uma alteridade radical no mundo ocidental, ou seja, a escolha de Fátima se transmuta em luta e combate por estar associada a uma entidade oposta ao Ocidente, lugar em que ela é posicionada. O preconceito a ser combatido é também advindo dos estereótipos que foram mobilizados sobre o islã, ao longo de muitos anos, de modo a produzir generalizações que ocultam a diversidade do mesmo (PINTO, 2010), além de minimizarem ou silenciarem as contradições do próprio mundo ocidental.

O hijab é, muitas vezes, entendido no Ocidente como um símbolo da opressão feminina, do atraso, além de, em especial após 2001, ser associado ao estigma do islã terrorista. Por outro lado, embora a reportagem ressalte o preconceito, Pinto (2010) aponta que, no Brasil, a concepção que atrela o islã ao terrorismo com a queda das Torres Gêmeas concorria, em 2001, com os discursos de cunho positivo veiculados na novela $O$ Clone. 
Ainda que haja preconceito, a arena de embate de sentidos envolvida na escolha do uso do véu islâmico não monopoliza o discurso da intolerância, pois é possível que haja a um só tempo, na construção discursiva sobre o Brasil contemporâneo, o país da hospitalidade, que abarca diferenças, e também o da intolerância, que destila o preconceito (SOUZA; ZOLIN VESZ, 2018).

Outrossim, a singularidade da história de Fátima se repara no subtítulo, pois, ao usar o véu, Fátima "sentia medo por estar no Brasil" e se morasse no Líbano seria considerada uma mulher comum. Os trechos concernem ao pressuposto de que o uso do véu é restrito a uma região específica do mundo, o Oriente, refutando-se o caráter religioso que está além do âmbito cultural e varia de acordo com a vertente do islã. Além disso,ainda que a principal parcela de muçulmanos esteja no Oriente Médio e Norte da África, é possível encontrá-los em qualquer região do mundo. Vale ressaltar que no Brasil há uma significativa comunidade de muçulmanos, tanto imigrantes advindos do Oriente quanto brasileiros convertidos, e constata-se ainda que "o número de convertidos na comunidade muçulmana do Rio de Janeiro passou de 15\% em 1997 para 85\% em 2009" (PINTO, 2010, p. 211). Ou seja, esses convertidos podem ou não optar por utilizar as vestimentas características do islã, dependendo da vertente em que escolham se inserir, por conta disso, o uso do véu não se restringe somente a pessoas advindas de países afora.

Além disso, o medo de usar o véu e a noção de que não sentiria tal medo no Líbano são construções que retomam uma vez mais o caráter antagônico entre o estilo de vida ocidental e o islã. Importante ressaltar que, por outro lado, o medo relatado se contradiz com os ideais ditos ocidentais de liberdade feminina, que apontam, quando em contradição com a mulher oriental, a liberalidade da escolha de vestimenta e a autorregulação do corpo feminino. Ao se enfatizar o medo de usar o véu islâmico durante o dia, símbolo de uma alteridade radical, não se discute, por exemplo, o medo da mulher ocidental em utilizar uma minissaia no período noturno. Para além dos véus e saias, ou da localização aqui ou lá, a liberdade para escolha da vestimenta está justaposta por sistemas de poder que ratificam a opressão sobre o corpo feminino - esteja ele no Brasil ou no Líbano.

\section{Excerto 3 - Tornei-me muçulmana por convicção}

Até hoje fico perplexa com o número de pessoas que me perguntam por que me converti, como se eu tivesse escolhido viver em uma prisão por causa de um véu ou da forma de me vestir. 
O trecho acima se atém à ideia do véu como símbolo do aprisionamento vivido pelas mulheres seguidoras do islã. Apesar de ser visto, majoritariamente, de forma pejorativa e retrógrada por aqueles que se proclamam ocidentais, o olhar de muitas mulheres muçulmanas acerca dessa questão pode não ser negativo, já que a utilização do hijab simboliza a sua fé e orgulho de fazer parte de sua religião, variando de acordo com a vertente do islã com a qual se identifique.

Atrelada ao uso do véu, a expressão "reclusão portátil”, utilizada pela antropóloga Hanna Papanek (1982 apud ABU-LUGHOD, 2012), refere-se à sensação de liberdade das paquistanesas com as quais realizou um estudo. Com isso, a autora concluiu, por meio dos relatos delas, que ao utilizarem os véus e/ou vestimentas características das mulheres muçulmanas, elas se sentiam protegidas dos olhares de desconhecidos e, assim, funcionariam como "casas móveis", que garantiriam a inviolabilidade delas. Da mesma forma, Doha, a entrevistada nessa matéria de reportagem, pode utilizar o seu hijab tanto para reforçar sua religião quanto para não se sentir exposta no cotidiano que, como indicado no trecho e já discutido no excerto 1, foi uma escolha dela, não podendo ser considerada como "uma prisão".

\section{Excerto 4 - A luta de Fátima para usar seu véu islâmico e combater o preconceito \\ Passei a me sentir mais bonita desde que comecei a usar o hijab, o véu do islamismo. Realçou meu rosto.}

O excerto 4 possui um caráter inusitado de acordo com o senso comum partilhado no Ocidente a respeito do uso do hijab, pois além de ter feito a escolha de utilizar o véu (como discutido no excerto 2), Fátima aprecia o seu uso, afirmando sentir-se mais bonita desde que começou a usá-lo e que realçou o seu rosto. Este fragmento se contrapõe ao caráter de símbolo da opressão que, majoritariamente, é atribuído ao véu islâmico e, simultaneamente, refuta a ideia de imposição sobre esse uso. Notamos que a construção de Fátima como uma mulher muçulmana se consolida com a adesão ao uso da vestimenta e que sua satisfação coloca em circulação enunciados que enaltecem a religião e o uso do véu.

Neste sentido, uma figura de grande destaque é a ativista paquistanesa Malala Yousafzai, que mesmo após se tornar conhecida mundialmente por sua famosa 
autobiografia e ter sido laureada com um Prêmio Nobel, continua vestindo roupas comuns paquistanesas (BASTOS, 2016). Assim, mesmo sob a égide da liberdade e autonomia ocidentais, Yousafzai decidiu continuar a usar o hijab que tanto combina consigo mesma, em sua opinião, e ainda simboliza a sua fé.

Na ordem do discurso, o sujeito fala de um determinado lugar, não sendo, portanto, plenamente autônomo em suas práticas discursivas (FOUCAULT, 2008), o que, por outro lado, não significa que tal sujeito não possa se perceber como dono das próprias escolhas. Trata-se de "[...] um lugar determinado e vazio que pode ser efetivamente ocupado por indivíduos diferentes" (FOUCAULT, 2008, p. 107). A multiplicidade de concepções sobre o uso do véu islâmico aponta para as posições ocupadas por diferentes indivíduos. Os enunciados que apontam para a prática do uso do véu como uma escolha do indivíduo não se originam no relato das brasileiras Fátima e Doha, mas estão dispersos em uma malha discursiva que alcança, inclusive, mulheres muçulmanas que vivem no Oriente Médio, na Europa, em diversas partes do globo terrestre.

Os efeitos de sentidos colocados em circulação por relatos como o de Doha, Fátima, Malala e outras milhares de muçulmanas que usam o véu islâmico no Ocidente, ao nosso ver, sinalizam a multiplicidade não apenas do islã, como também do espaço polissêmico em que se constrói o mundo contemporâneo. O perigo da história única, que aponta uma verdade irrefutável sobre o véu islâmico, silencia outras verdades, outras vozes e histórias de vida que podem nos permitir uma compreensão sobre o mundo social - que não é único e fixo, mas móvel, flexível e fragmentado.

\section{CONSIDERAÇÕES FINAIS}

Neste artigo, analisamos os relatos de duas brasileiras que usam o véu islâmico como prática religiosa no Brasil e afirmam utilizarem a veste por livre escolha. Concebemos tais relatos como vozes díspares frente aos discursos comumente percebidos no mundo ocidental sobre o véu islâmico, pois colocam em circulação enunciados que se distanciam daqueles que conectam o hijab à submissão feminina. A possibilidade de escolha feminina pelo uso do véu contradiz os discursos dominantes que apontam que tal vestimenta é imposta às muçulmanas. Ao mesmo tempo, tais relatos nos permitem entender que tal escolha não é isenta de complicações, o que se denota na confissão do 


\section{REVISTA $\mathbf{X}$}

medo e do preconceito sentido por essas mulheres.

Os excertos selecionados nos permitiram perceber as implicações e os efeitos de sentido de tais enunciados, que, muitas vezes, se deslocam entre polaridades, tais como a liberdade daquela que escolhe adotar o véu e a opressão com a qual é vista pelos olhares daqueles que desconhecem o islã. Escolher usar o véu, conforme analisado, coloca em funcionamento outros discursos sobre o hijab no mundo ocidental, o que, ao nosso ver, pode provocar fissuras nas concepções generalizantes. Estas são insuficientes para traduzir a complexidade e diversidade do mundo social.

O véu é tecido por fios, mas também por e na prática discursiva - entre a opressão e a escolha, a resistência e a obediência, sob a proteção ou a sujeição, as escolhas femininas em se associar a essa ou àquela formação discursiva contribuem na construção de subjetividades, que colocam em circulação diferentes verdades que não são únicas nem aqui nem acolá.

\section{REFERÊNCIAS}

ABU-LUGHOD, L. As mulheres muçulmanas precisam realmente de salvação? Reflexões antropológicas sobre o relativismo cultural e seus Outros. Revista Estudos Feministas, v.20, 2012, p.451-470. Disponível em: <https://doi.org/10.1590/S0104026X2012000200006 >. Acesso em: 23 ago. 2020.

BASTOS, L. M. P. C. Fetiche neo-orientalista: o problema da autorrepresentação do subalterno e as autobiografias de mulheres muçulmanas. 1.ed. Goiânia: Editora UFG, 2016.

BISWAS, D. Tornei-me muçulmana por convicção, s/d. Fotografia. Disponível em: $<$ https://revistamarieclaire.globo.com/EuLeitora/noticia/2018/05/eu-leitora-tornei-memuculmana-por-conviccao.html>. Acesso em: 23 ago. 2020.

CLAUDIA. A luta de Fátima para usar seu véu islâmico e combater o preconceito. Disponível em: <https://claudia.abril.com.br/sua-vida/a-luta-de-fatima-para-usar-seu-veuislamico-e-combater-o-preconceito/>. Acesso em: 23 ago. 2020.

FOUCAULT, M. A arqueologia do saber. 7.ed. Rio de Janeiro: Forense Universitária, 2008.

FOUCAULT, M.; MACHADO, R. (Org.). Microfísica do poder. 25.ed. São Paulo: Graal, 2012. 
GROSFOGUEL, R. Breves notas acerca del Islam y los feminismos islâmicos. In: GROSFOGUEL, R. (Org.). Feminismos Islámicos. 1.ed. Caracas: Fundação Editorial El perro y larana, p. 10-37, 2016.

KUMARAVADIVELU, B. A Linguística Aplicada na era da globalização. In: MOITA LOPES, L. P. (Org.). Por uma linguística aplicada indisciplinar. 1.ed. São Paulo: Parábola Editorial, p. 129-148, 2006.

LAMRABET, A. El velo (hiyab) de las mujeres musulmanas: entre la ideologia colonialista y el discurso islâmico: una visión decolonial. In: GROSFOGUEL, R. (Org.). Feminismos Islámicos. 1.ed. Caracas: Fundação Editorial El perro y larana, p. 39-62, 2016.

LIMA, K. Descobrindo o Islã no Brasil. 1ªed. São Paulo: Editora Hedra, 2016.

MARIE CLAIRE. Tornei-me muçulmana por convicção. Disponível em: $<$ https://revistamarieclaire.globo.com/EuLeitora/noticia/2018/05/eu-leitora-tornei-memuculmana-por-conviccao.html>. Acesso em: 23 ago. 2020.

MOITA LOPES, L. P. Uma lingüística aplicada mestiça e ideológica: Interrogando o campo como lingüista aplicado. In: MOITA LOPES, L. P. (Org.). Por uma linguística aplicada indisciplinar. 1.ed. São Paulo: Parábola Editorial, p. 13-44, 2006.

PINTO, P. G. H. R. Islã: Religião e Civilização- uma abordagem antropológica. 1.ed. Aparecida: Editora Santuário, 2010.

SAID, E. W. Orientalismo: o Oriente como invenção do Ocidente. 1.ed. São Paulo: Companhia das Letras, 2007.

SALVADOR, M. A luta de Fátima para usar seu véu islâmico e combater o preconceito, s/d. Fotografia. Disponível em: <https://claudia.abril.com.br/sua-vida/a-luta-de-fatimapara-usar-seu-veu-islamico-e-combater-o-preconceito/>. Acesso em: 23 ago. 2020.

SOUZA, D. S.; ZOLIN-VESZ, F. Da hospitalidade à intolerância ao migrante árabe: construções discursivas sobre um mesmo Brasil. Trabalhos em Linguística Aplicada, Campinas, v.57, n.2, p.877-893, 2018. Disponível em <https://dx.doi.org/10.1590/010318138651844362911>. Acesso em: 23 ago. 2020.

ZOLIN-VESZ, F.; FELTRIN, K. P.; SOUZA, N. K. V. 2019. Gênero e neo-orientalismo em autobiografias de mulheres muçulmanas. Polifonia, v.26, n.44, p.160-163, 2019. Disponível: $\quad<$ https://periodicoscientificos.ufmt.br/ojs/index.php/polifonia/article/view/9439>. Acesso em: 23 ago. 2020.

Recebido em: 05 jul. 2020. Aceito em: 24 ago. 2020. 